\title{
ARCHEOLOGICKÁ PROSPEKCE VRCHOLNĚ STŘEDOVĚKÉHO AREÁLU BOJIŠTĚ U LIPAN (OKRES KOLÍN)
}

\author{
LENKA MILITKÁ - ZDENĚK ŠÁMAL
}

\begin{abstract}
Abstrakt: Přispěvek je zaměřn na zhodnoceni dosavadních výsledků bádání, které prinesly tři sezóny archeologického výzkumu bojiště u Lipan (okr. Kolín). Projekt, koncipovaný jako mezioborový, si klade za cíl upřesnit informace o lokalizaci a průběhu vojenského střetnutí mezi husitskými radikály a koalicí katolikủ a umirněných utrakvistů 30. května 1434, ale rovněž zajistit aktivní archeologickou památkovou péči pro potenciálně ohroženou lokalitu, jež přitahuje k nelegálním zásahưm uživatele detektorů kovů. Základem celého projektu je terénni identifikace a dokumentace areálu bojiště, která probíhá pomocí standardních i nových dokumentačnich metod.
\end{abstract}

Klíčová slova: Lipany - husité - archeologická prospekce-bojiště-detektor kovů.

\section{Archaeological prospection of a high-medieval battlefield near Lipany (Kolín district)}

Abstract: This contribution focuses on the assessment of the results of three seasons of archaeological research into a battlefield near Lipany (Kolin district). The project, conceived as an interdisciplinary one, sought to specify information about the site and the course of a military clash between Hussite radicals and the coalition of Catholics and moderate Utraquists on 30 May 1434. Another objective was to provide effective archaeological heritage care for the potentially endangered site attracting illicit metal detecting. The project was based on the terrain identification and documentation of the battlefield with the use of both standard and new documentation methods.

Key words: Lipany - Hussites - archaeological prospection - battlefield-metal detector.

\section{Úvod}

Od dubna roku 2016 až do současnosti probíhá terénní část výzkumného projektu vedeného Národním památkovým ústavem, jehož hlavní náplní je archeologický průzkum areálu konfliktu na katastrálním území středočeských obcí Lipany a Vitice (obr. 1). Primárním cílem výzkumu je pomocí archeologické prospekce zajistit a odborně dokumentovat hmotné pozůstatky významného vojenského střetu sklonku první fáze husitských válek, který je znám jako bitva u Lipan.

V prvé řadě jde o upřesnění prostoru, v němž se bitva odehrála. Dále také o zajištění aktivní archeologické památkové péče pro potenciálně ohroženou lokalitu, která dlouhodobě láká k nelegálním návštěvám uživatelů detektorů kovů. Terénní část výzkumného projektu se opírá především o systematickou prospekci pomocí detektorů kovů a povrchových sběrů. Detektorová prospekce se zaměřuje na vyhledávání jednoznačně identifikovatelných kovových artefaktů především militární povahy, jejich dokumentaci a vyhodnocování jejich prostorových vztahů (Biederman a kol. 2017, 5-10; 2018, 46-51).

V teoretické části projektu jsou revidovány historické prameny, stejně tak mapové podklady ukazující na postupné proměny a vývoj historické krajiny (Biederman a kol. 2017, 1-5). Je důležité zmínit, že v kontextu husitských válek patří stř̌et u Lipan $\mathrm{k}$ těm válečným událostem, které byly podrobně popsány jak současníky, tak i pozdějšími kronikáři a badateli (např. Urbánek 1934; Čornej 1992; 2003). Přesto se z hlediska faktického popisu události ukazuje, že při snahách o rekonstrukci průběhu střetnutí a jeho přesnou lokalizaci disponujeme spíše rozpornými a nejednoznačnými svědectvími, velkou řadou dohadů a hypotéz. Archeologie sice na všechny otázky odpověd' nepřinese, může však svými metodami o poznání o průběhu události významně rozšírit (Biederman a kol. 2018, 31-51).

Dosavadní průběh terénního průzkumu přináší kromě naplňování primárního cíle i další nové informace v podobě souborů nekovových a především kovových artefaktů, chronologicky dalece přesahujících rámec jediného pozdně středověkého vojenského střetu, který trval pouhých několik hodin (Militká-Šámal 2017, 114-117; Militká-Beneš-Šámal 2018, 663-678). 


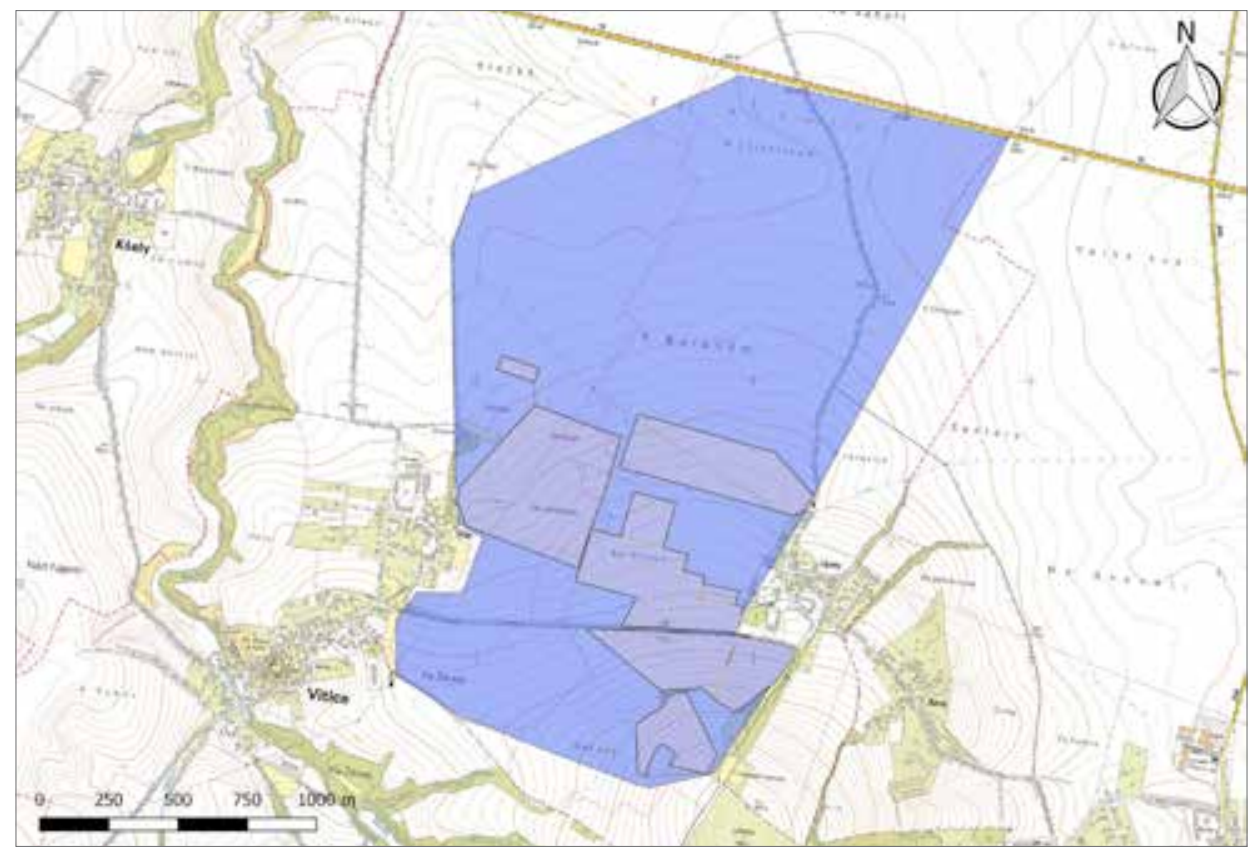

Obr. 1. Vymezený prostor zájmového území mezi obcemi Vitice, Hřiby a Lipany, směrem ke státní silnici Praha-Kolín. Vyznačeny jsou zkoumané plochy v letech 2016-2018. Zpracoval J. Pařez.

Abb. 1. Abgegrenzter Raum des Interessensgebietes zwischen den Gemeinden Vitice, Hřiby und Lipan, in Richtung Staatsstraße Prag-Kolín. Gekennzeichnet sind die in den Jahren 2016-2018 untersuchten Flächen. Bearbeitung J. Pařez.

\section{Historický rámec}

Podle písemných zpráv stanulo vojsko radikálních husitů proti koalici umírněných husitů a katolíků zhruba v polovině vzdálenosti mezi Kouřimí a Českým Brodem (obr. 2). K samotnému střetu došlo v neděli 30. května 1434 o nešporách, tj. uprostřed odpoledne (Čornej 1992, 7; Biederman a kol. 2018, 35). Z písemných pramenů se dá usuzovat, že táborité a sirotci vybudovali svou vozovou hradbu na severozápadním svahu Lipské hory. Kromě závěrečné řeže přímo ve vozové hradbě radikálů se měl hlavní boj odehrávat na polích v blízkosti vesnic Lipany a Hřiby, přičemž část vítězných vojsk kališnicko-katolické aliance pronásledovala poražené radikály ve směru na Kolín. Navečer již bylo o vítězi definitivně rozhodnuto (Strnad 1891, 365; Biederman a kol. 2018, 32-36). Přestože u několika důležitých momentů střetu jsou písemné prameny zajedno, ${ }^{1}$ celkově si však spíše protiřečí. ${ }^{2}$ Jak přesně probíhala samotná řež, nelze, s výjimkou počáteční fáze bitvy, spolehlivě rekonstruovat (Čornej 1992; Biederman a kol. 2018, 32-37).

\section{Krajinný rámec areálu konfliktu u Lipan}

Vycházíme-li z předpokladu, že přírodní podmínky, poloha lidských sídel a cest určovaly pohyb vojsk terénem, měl bezpochyby ráz středověké krajiny mezi Českým Brodem a Kouřimí3

\footnotetext{
1 Vyzdvihuje se důležitost klamného manévru na straně koalice. Dále se prameny shodují v konstatování, že vpád do vozové hradby radikálů uskutečnil elitní oddíl, který původně tvořil zadní skupinu, ale při obratu se ocitl v čele (Biederman a kol. 2017, 1-2).

2 Obšírné shrnutí historických souvislostí a příčin vojenského střetu, spolu s kritikou písemných pramenů, shrnul prof. P. Čornej, CSc. (Biederman a kol. 2018, 32-37).

3 Sledované území leži ve středních Čechách, podle současného administrativního členění v okrese Kolín, 5 km na severovýchod od Kouřimi a 7,5 km jihozápadně od Českého Brodu.
} 


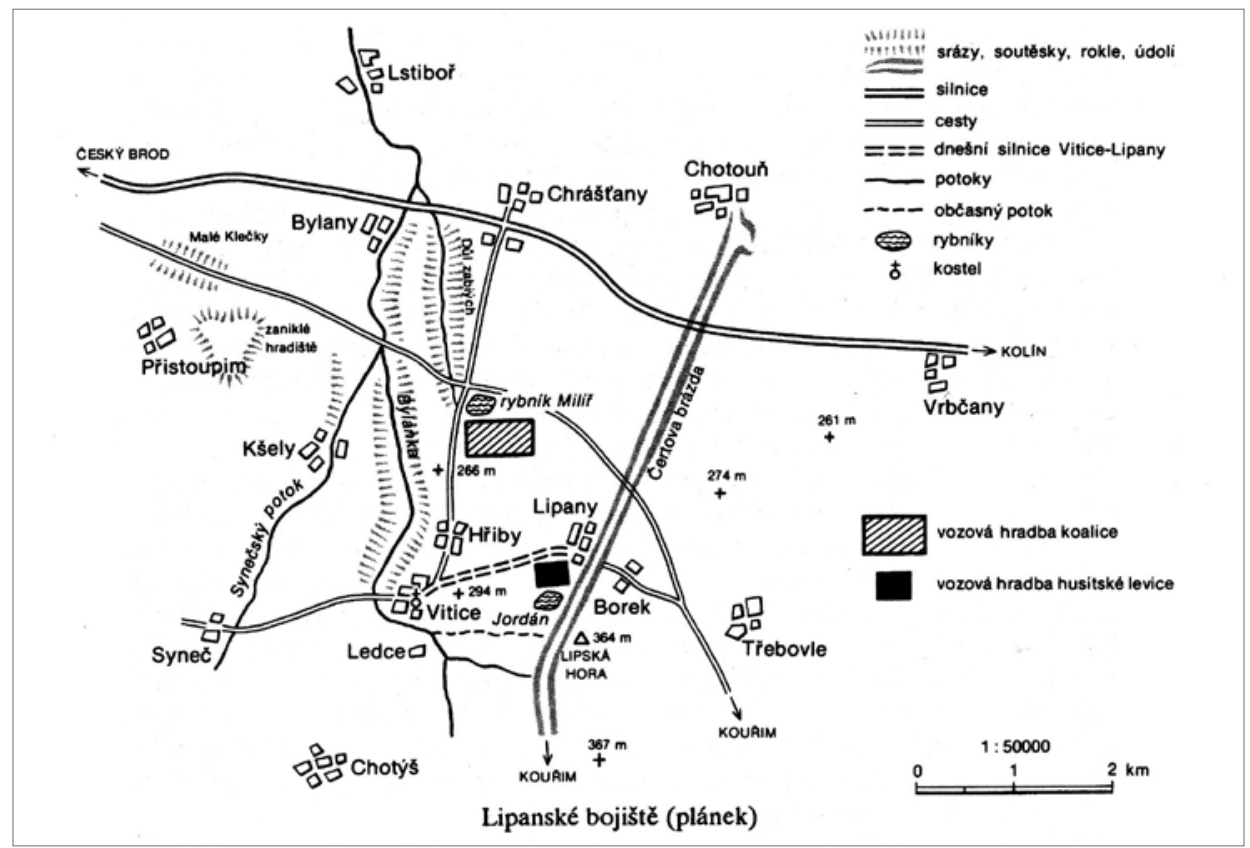

Obr. 2. Lipany. Rekonstrukění plánek bojiště. Podle Čornej 1992.

Abb. 2. Lipan. Rekonstruktionsskizze des Schlachtfeldes. Nach Čornej 1992.

významný vliv na volbu místa střetu i jeho samotný průběh. Krajinou našeho odborného zájmu je prostor mezi obcemi Lipany, Vitice, Hřiby a místní částí Borek v obci Třebovle, který se podle dosavadních závěrů stal dějištěm bitvy.

Je logické, že na krajinu v současnosti i v minulosti působila řada vlivů a stopy v ní zanechávají procesy různě dlouhého trvání. Je proto nutné pohybovat se v širších souvislostech a sledovat vývoj nejen před bitvou, ale také po ní. Základem takto pojatého přístupu se v posledních letech staly metody nedestruktivního výzkumu. Pro sestavení obrazu krajiny v době střetu vojsk jsou bezesporu zásadní staré mapové podklady obsahující informační potenciál, který do nedávné doby nebyl plně využit. ${ }^{4}$ Teoretická část projektu se samožrejmě věnuje i kritickému zhodnocení orální lokální historie, které přináší rovněž velmi zajímavé a cenné informace. Právě z mapových podkladů a orální historie vyplývá, že se do současnosti krajinný ráz zájmového území zásadně nezměnil. Krajina zůstává tradičně zemědělská a rozsah osídlených ploch v malých obcích se rovněž výrazně nemění. Změny, které razantněji zasáhly do rázu krajiny sledovaného prostoru, se odehrály především během kolektivizace v 50. a 60. letech 20 . století, kdy proběhlo scelování polností a rušení některých polních cest (Biederman a kol. 2017, 4-5). Další zásadní překážkou, jež mohla do určité míry ovlivnit samotnou bitvu, byla tzv. Čertova brázda. Dnes je na samém kopci Lipské hory zřetelná jenom nepatrná terénní deprese, ale lze předpokládat, že v době bitvy se jednalo o hluboký, obtížně překonatelný př́íkop (Kuffner-Miškovský 1899, 36). V nedávné době se tento geomorfologický krajinný prvek stal předmětem výzkumu (ŠtukaNový 2014, 39). Ze studia mapových podkladů a z informací místních obyvatel je zřejmé, že celý prostor našeho odborného zájmu byl výrazně bohatší na vodní zdroje pramenící na svahu Lipské hory. Dále předpokládáme, že v prostoru bojiště byly dnes rozorané pásy luk, mezí a remízků.

4 Nejpřínosnějšími informačními zdroji pro předmětné území jsou mapy stabilního katastru a jejich porovnání se situací zachycenou na mapách prvního vojenského mapování (Biederman a kol. 2017, 4-5). 
Stejně tak nelze opomenout fakt, že se ve sledovaném prostoru vyskytovaly dnes již neexistující výrazné terénní deprese, které mohly významným způsobem ovlivnit některé fáze a okamžiky bitvy (Biederman a kol. 2017, 5-10). ${ }^{5}$ Ke změnám došlo rovněž u komunikací vedoucích z Lipan do Vitic a Hřibů. ${ }^{6} \mathrm{~V}$ současné době je výrazným prvkem v krajině pomník na pamět' bitvy postavený na vrcholu Lipské hory v roce 1881 . Z hlediska archeologické památkové péče je nutné zmínit fakt, že tato kulturní památka z roku 1965 získala o třicet let později i ochranné pásmo, které zahrnuje také převážnou část ploch polností, kterých se dotýká samotný střet znepřátelených stran (Biederman a kol. 2017, 9). Památková ochrana areálu bojiště je v kontextu jiných podobných lokalit na území České republiky značně neobvyklá.

\section{Archeologie bojišt' ve světě a v České republice - vývoj a současný stav poznání}

Archeologický výzkum bojiště u Lipan je v ČR zatím první akcí svého druhu zaměřenou na období pozdního středověku. Česká bojištní archeologie však už má za sebou - anebo v realizaci - některé úspěšné výzkumy historicky mladších bojišt', časově spadajících zejména do období třicetileté války, tereziánských válek 18. století a prusko-rakouského konfliktu roku 1866. Tyto aktivity na našem území celkově zapadají do časového rámce vývoje specifického sub-oboru archeologie, kterou nazýváme „bojištni““, který se jako takový v zahraničí etabloval v 80. letech minulého století a byl spojen především s rozmachem technologie detekování kovů pod odborným vedením archeologů (blíže např. Koscelník 2013, 9-13; Biederman a kol. 2018, 37-42; Šámal 2018, 16-31).

Metod a postupů bojištní archeologie a její odbornou exploraci poprvé využili badatelé z USA, jejich evropští kolegové však téměř synchronně dospívali k obdobné praxi i jejímu teoretickému zhodnocení (Pollard 2009; Homann 2013). V USA byla s využitím detektorů kovů od roku 1984 odborně zkoumána oblast kolem Little Bighornu (stát Montana), kde v červnu indiáni pobili větší část 7 . kavalerie generála L. A. Custera. Do průzkumů se pod vedením D. Scotta a R. Foxe zapojili četní amatérští uživatelé detekčních př́strojů a byla zde využita i tzv. transektová metoda, předpokládající získaní reprezentativního vzorku kovových nálezů z prohledání vyčleněných asi $35 \%$ zájmového území (Scott 2010). Lokalizované a odborně vyzdvižené artefakty výsledného nálezového souboru souvisely především s výzbrojí bojujících stran - šlo o hroty šípů, olověné projektily, nábojnice, zápalky, části palných zbraní atd. (souhrnně Scott 2010).

Od té doby zkoumání bojišs' s využitím detektorů kovů zahrnulo v různých zemích širokou časovou škálu vojenských událostí od starověku až po novověk (např. Homann 2013; Krásný 2014). Metoda přispěla např́íklad k lokalizaci dějiště bitvy v Teutoburském lese (9 n. 1.) nebo méně známého střetnutí římských legií s Germány u dolnosaského Harzhornu (kolem 235 n. 1.; Schlüter 1992; Pöppelmann-Deppmeyer-Steinmetz 2013). V Německu se ale detektorová sondáž uplatnila zejména při archeologickém výzkumu bojišt' třicetileté války, jako např́íklad u Lützenu nebo Wittstocku (1632, resp. 1636; Brock-Homann 2011; Schürger 2009). Ve Velké Británii archeologie bojišt' získala definitivní odborné uznání koncem 90. let minulého století. Původní zásluhy na rozvoji archeologického sub-oboru využívajícího potenciál detektoru kovů se přisuzují aktivitám několika amatérů na bojištích tzv. Války růží u Towtonu (1461) a anglické občanské války u Sedgemooru (1685). Amatérští badatelé zde původně patřili k té menšině

\footnotetext{
5 Zásadní změny, které v krajině nastaly, se týkají zejména zavezení výrazných depresí kolem obce Lipany, které maji podle informací od starousedlíků mocnost až $3 \mathrm{~m}$.

6 Podle starších mapových podkladů se také změnila sít' komunikací spojujících Lipany a Hřiby. Současná asfaltová spojnice Lipany-Vitice má předchůdce v polní cestě, která je poprvé zachycená na mapách stabilního katastru. Nahradila dvě původní komunikace - jihozápadní cestu, která procházela pod svahem Lipské hory do Vitic, a komunikaci, která spojovala severní část obce Lipany a severní část obce Hřiby (Biederman a kol. 2017, 4-5).

7 Tento stav je dán specifickou povahou vymezení takové památky v terénu. Často chybí jakékoli opěrné vodítko o rozsahu prostoru bojiště, zejména u středověkých střetů často není možné samotné místo vůbec zachytit. V případě, že je místo střetu známo, jedná se většinou o velké plochy v terénu. Stanovení památkové ochrany však v praxi samo o sobě samozřejmě nestačí, a aby došlo k záchraně cenných archeologických informací, je nutné přistoupit k provádění systematických povrchových průzkumů lokalit, jako je lipanské bojiště, kde zanikají archeologické informace v důsledku zemědělské činnosti i činnosti nelegálních hledačů s detektory kovů.
} 
hledačů, která nálezy zanášela do map a důsledně evidovala. Jejich letitá vytrvalost nakonec zaujala i profesionální archeology. Tímto způsobem vznikly první odborně vedené výzkumné projekty a během několika let metoda našla na britských ostrovech uplatnění na desítkách bojišt' z různých období (Sutherland-Holst 2005; Pollard 2009; Homann 2013).

Výzkum bojišt' a areálů spojených s vojenskými aktivitami je samozřejmě nejen u nás mnohem staršího data. $Z$ českých výzkumů je nutno připomenout například výzkumy hradů obléhaných během husitských válek či husitských táborů v 50. a 60. letech minulého století (Šámal 2018, 16-31). Ještě bez využití detektorů kovů v roce 1988 začínal časově i plošně rozsáhlý výzkum bojiště z roku 1647 u západočeské Třebele vedený V. Matouškem (Matoušek 2006). Zkušenosti z realizace tohoto široce koncipovaného záměru bylo později možné využít při výzkumu dalšího bojiště z třicetileté války z roku 1620 u Rakovníka. Tady už se detektory kovů v odborném rámci uplatnily i na rozsáhlejších plochách vojenských aktivit na místě někdejších vojenských táborů, polních opevnění a lokalit vojenských střetů (Blažková a kol. 2011; Šámal 2018). Stejným způsobem pak byly vedle dalších metod využity i při zkoumání bojištního areálu z roku 1621 u Rozvadova (Matoušek 2011; 2013; Hrnčiřík 2012; 2013; Matoušek-Hrnčiřík-Šámal 2018). Detektory kovů byly také součástí průzkumu Volarské šance nebo švédského tábora u Staré Boleslavi (Beneš-Kubů-Török 2005, 461-480; Krásný 2014). Z mladších konfliktů je pak ukázkou postupů bojištní archeologie výzkum M. Holase u Náchoda, kde v roce 1866 proběhl dílčí střet pruských a rakouských jednotek (Holas 2017, 18-23). Rozsáhlá dokumentace pozůstatků prusko-rakouského konfliktu pomocí detektorů kovů se uskutečnila i v roce 2017 před zahájením ZAV na stavbě dálnice D11 mezi Hradcem Králové a Jaroměří, kde však odborné vyhodnocení výsledků teprve probíhá. ${ }^{8}$

Samostatnou kapitolou jsou výzkumy spojené s 15 . stoletím a především obdobím husitských válek. Do nástupu detektorů kovů se výzkumy soustřed'ovaly na fortifikace a opíraly se o standardní archeologické metody a zkoumání ženijních pozůstatků spojených s obléháním nebo obranou hradů, prrípadně se souvisejícími stavebními činnostmi (Koscelník 2013, 9-13; Koscelník-Kypta-Savková 2013, 574-598; Meduna 1994, 243-250; Novobilský 2008; Šámal 2018, 50-59). V zimě 1989/1990 byl u hradu Skála na Přešticku archeology poprvé použit i detektor kovů (Novobilský 2008, 9). Další možnosti této metody naznačil výzkum plzeňského Západočeského muzea, vedený M. Novobilským v okolí pozůstatků hradu Lopata v Kozelském polesí v letech 1995-1999. Hrad byl zničen na přelomu let 1432-1433 po čtyřměsíčním obléhání husitskými oddíly, do dnešních dnů se však dochovaly stopy spojené především s obléhacími pracemi. Tyto zemní relikty byly při průzkumu geodeticky zaměřeny a zmapovány, detekční metoda pak přinesla množství artefaktů dokumentovaných souřadnicemi. To mimo jiné přispělo k dokreslení konkrétního obrazu situace spojené s dobýváním hradu v období husitských válek, která zároveň nesla obecnější rysy typické pro zažité vojenské postupy a metody tehdejší doby (Novobilský 2008).

Od dob výzkumů na hradě Lopata se česká archeologie v tomto směru posunula značně kupředu. Z mnoha př́kladů stojí za připomenutí výzkumy východočeského archeologa $\mathrm{D}$. Vícha z Regionálního muzea ve Vysokém Mýtě (Vích 2017, 83-109) nebo výzkum v okolí Nového hradu u Kunratic, kde se však badatelé vedle cenného srovnání analogických situací soustředili především na dokumentaci a zaměřování terénních pozůstatků spojených s dobýváním hradu v roce 1420 (Kypta-Podliska 2014, 609-632). Významnou roli naopak detektory kovů sehrály při komplexním výzkumu bezprostředního okolí zříceniny hradu Sion, kde se v roce 1437 odehrával poslední boj známého táborského hejtmana Jana Roháče z Dubé (Koscelník 2013, 45-89; Koscelník-Kypta-Savková 2013, 574-598). Z nověji publikovaných výzkumů pak nutno připomenout i hrady Kalich a Panna u Litoměřic, kde detektory opět napomohly k naplnění jedné z kapitol širšího badatelského záměru (Lehký-Sýkora 2016). ${ }^{9}$

8 Za laskavou informaci děkujeme Mgr. P. Hejhalovi (UHK).

9 Podrobněji k vývoji používání detekčních zařízení při archeologických výzkumech v zahraničí a v České republice Biederman a kol. 2018, $37-42$. 
Až do zahájení lipanského projektu v ČR ovšem nebyly prospekční metody bojištní archeologie v systematickém a dlouhodobějším měřítku uplatněny pro otevřená bojiště starší, než jsou místa konfliktů raného novověku. Výzkumy týkající se husitských válek se soustřed’ovaly do okolí stálých či dočasných fortifikací, tedy na místa v krajině jasně definovaná, kde lze se znalostí dobového vojenství relativně přesně vymezit rozsah zájmové plochy výzkumu. Předpokládaná místa dynamického střetu dvou vojsk ve volném terénu prredstavují v tomto směru odlišný typ badatelského zadání. Často jen neurčitě naznačená místa středověkých bitev jsou pro rozsah a proměnlivost lokalit $\mathrm{v}$ průběhu staletí a $\mathrm{z}$ důvodů obvykle méně konkrétní a nejednoznačné výpovědi pramenů terénem badatelsky náročnějším. Př́iklady z Velké Británie, jako jsou výzkumy bojiště Bannockburn 1314 (Biederman a kol. 2018, 42; Šámal 2018, 16-17) nebo Bosworthu 1485 (Foard-Curry 2013), a z dalších evropských lokalit, např́íklad polského Grunwaldu 1410 (Nowakowski 2015,79-87) nebo mad’arského Moháče (Szabó-Bertók-Gáti-Szajcsán 2016), však ukazují, že metody bojištní archeologie lze využít i v případě středověkých bojišt' ve volné, obvykle zemědělsky obdělávané krajině. Výsledek ale není možné očekávat bezprostředně v rámci několikadenní či dokonce jednorázové akce.

Je žádoucí zdůraznit, že sám předmět bojištní archeologie, tedy zkoumání bojiště a pozůstatků „bitvy“ v otevřeném terénu, spadá podle některých badatelů pouze do jedné z kategorií širšího pojmu ,archeologie konfliktních areálü“ (např. Koscelník 2013, 7-8). Jak bylo výše naznačeno, systematická detektorová prospekce spojená se zaměřováním nálezů a vyhodnocováním jejich prostorových vztahů - tedy základ metody bojištní archeologie - byla v ČR zatím využívána pouze pro novověké konflikty.

V př́ípadě výzkumů hradů obléhaných během husitských válek pak sice v souvislosti s lipanskou bitvou panuje shoda časová, nikoli však situační. V okolí stálých i dočasných fortifikací lze totiž východiska výzkumu opř́t o bod v terénu jasně definovaný - o samotnou fortifikaci. S kvalifikovaným odhadem postupů a možností tehdejšího vojenství, resp. jeho techniky a technologií, pak lze i v okolí fortifikace poměrně přesně vymezit zájmovou plochu výzkumu, danou především dostřelem zbraní a konfigurací významných prvků terénu. Dynamický střet dvou vojenských těles $\mathrm{v}$ otevřeném terénu představuje $\mathrm{v}$ tomto směru jiný typ badatelské výzvy. Zde situaci dále komplikuje nejen nejistá výpověd' písemných pramenů, ale i proměnlivost terénu v průběhu staletí - nemluvě už o tom, že obvykle prostředí hospodářsky po staletí obdělávaných lokalit, kde předpokládáme dějiště bitev, je ke kovovým artefaktům podstatně méně „šetrnějši““ než lesní areály obklopující zříceniny hradů.

Úvahy provázející př́ípravu lipanského projektu a jeho dosavadní průběh se však mohly opírat o zkušenosti a výsledky chronologicky i metodicky obdobných výše uvedených projektů v zahraničí.

$\mathrm{Z}$ těchto úhlů pohledu pak lze výzkum bojiště u Lipan považovat za experiment, který kromě archeologických poznatků ke konkrétní historické události může přinést i další profit v podobě prověření a specifikace metod bojištní archeologie na lokalitě pozdního středověku.

\section{Dosavadní archeologické bádání související s areálem bojiště}

Záznamy o archeologických aktivitách, jež lze spojit s lipanským bojištěm, se v literatuře poprvé objevují v roce 1892. Jedná se o zápis odborné komise, která se v Lipanech sešla na základě oznámení bývalého starosty obce J. Fialy. Obsahem tohoto jednání byl nález údajného hrobu vůdce radikálů Prokopa Holého. Komise sestávala z významných badatelů tehdejší archeologické obce v čele s J. L. Píčem a J. Kalouskem. Lokalizace hrobu se bohužel nepotvrdila, ale ze zprávy vyplývá, že se ctihodní vědci zabývali informací starousedlíků o nálezu dvou lebek odkrytých při budování cesty v roce 1882 (Prášek 1892, 632; Oliva 1954, 1-8). Úvahy o spojení tohoto nálezu s hrobem Prokopa Holého a Prokůpka, kteří v bitvě u Lipan zahynuli, však nelze považovat ani za hypoteticky doložitelné. Ostatně negativní výsledek přinesl i výzkum českobrodského muzea v roce 1957 (Bednařík 1957; Sklenář 2011, 169). Avšak poloha údajného místa posledního odpočinku Prokopa Holého se udržela v místním historickém povědomí, 
jak to dokládají např́iklad paměti milčického rychtáře Františka J. Vaváka spolu s jeho mapou lipanského bojiště z roku 1788 (Skopec 1924, 50), ale i grafický list zobrazující smrk na zahradě Grossen Grab zu Lipan z roku 1849 (Heber 2012, 263).

$\mathrm{O}$ případných dalších místech masových hrobů souvisejících s bitvou jsou v zápisu zmiňované komise také informace o nálezech lidských koster „,bez všech přidavkư““, které byly objeveny př́mo v obci Lipany, dále pak zejména na severozápadní straně a méně jihozápadně od obce. ${ }^{10}$ Údaje o nálezech lidských skeletů souvisejících s lipanským bojištěm je ovšem nutné posuzovat se značnou dávkou opatrnosti, nebot' v oblasti s výrazným pravěkým osídlením je velká pravděpodobnost, že se mohlo jednat také o hroby pravěkého stáří. Důležité informace o archeologických nálezech, které lze spojit s lipanským bojištěm, popsal právě J. Fiala, který uvádí, že se při orbě na polnostech mezi Lipany a Hřiby nacházely běžně železné koule různých velikostí, ostruhy od vojenských bot a různé zlomky zbraní (Prášek 1892, 632). O existenci dalších nálezů, které by mohly mít souvislost s místem konfliktu, hovoří také nálezové zprávy z roku 1946, uložené v archivu Archeologického ústavu AV ČR, v. v. i., Praha. ${ }^{11}$

První profesionální archeologické průzkumy, ke kterým jsou k dispozici nálezové zprávy, proběhly na sledovaném území v 80 . letech 20 . století formou povrchových sběrů - jejich výsledkem byly převážně nálezy z období pravěku a raného středověku (Prkno-Vávra-Zapářka 1987, 109, 225). Dosavadní dílčí výsledky z prvních dvou výzkumných sezón předmětného projektu byly již rovněž publikovány (Biederman a kol. 2017, 5-10; 2018, 46-51; Militká-Š́ámal 2017, 114-117; Militká-Beneš-Šámal 2018, 663-678).

\section{Archeologická prospekce bojiště}

Vzhledem $\mathrm{k}$ faktu, že zájmovou oblast na území katastrů tvoří zemědělsky obdělávané pozemky, jsou možnosti provádění povrchových průzkumů limitovány vegetačními fázemi roku a postupem zemědělských prací. Důležitým faktorem, který ovlivňoval archeologický výzkum, byly klimatické podmínky a způsob úpravy povrchu polí zemědělskou technikou.

Při terénní části archeologického výzkumu areálu lipanského bojiště byly využity nedestruktivní metody moderní archeologie, tj. terénní průzkum v kombinaci s prospekcí detektory kovů a zaměřováním archeologických nálezů pomocí souřadnic systému GPS. Detektorová prospekce probíhá výhradně na zemědělsky obdělávané půdě a pracuje s nálezy z ornice, a jako taková tedy nenarušuje archeologické situace zahloubené do podloží. Pro hledače s detektory kovů je prospekce takové lokality, jako je bojiště u Lipan, náročnější na čas i vynaložené úsilí, protože je nutné vyzvednout ze země každý kovový předmět, který je detekčním zařízením zjištěn. Právě to je jeden z faktorů, který průzkum komplikuje.

U raně novověkých bojišt' je standardním nálezem olověný projektil, při čemž lze využít schopnosti detektoru odlišit barevný kov od železa. V prŕípadě středověkého bojiště je však většina militarií vyrobena ze železa, a proto je nutné prověřovat většinu signálů. Přímo na lokalitě je prováděna selekce jasně určitelného recentního odpadu. Při značně vysoké kontaminaci zemědělské půdy recentním odpadem vyvstala otázka, do jaké míry je zemědělská krajina obecně zamořená novodobým odpadem nejrůznějšího charakteru. Z dosavadních zkušeností lze odhadnout zhruba $15 \mathrm{~kg}$ (sub)recentních železných artefaktů a fragmentů na jeden nález s vypovídací hodnotou. Experimentální prospekce na polích lipanského katastru prokázala, že ve čtverci o straně 10 metrů lze očekávat přibližně 60 předmětů ze železa a deset z barevných kovů. Při dvou testech byl takto vyjmut jeden artefakt, který je možno vztáhnout ke zkoumané události. S ohledem na tuto skutečnost je detektorová prospekce velmi náročná časově a klade i výrazné fyzické nároky na samotné hledače. I vzhledem k rozsáhlé ploše zkoumaného prostoru je zřejmé, že terénní výzkum probíhá velmi pomalu.

10 Další místo, kde by bylo možné hledat masové hroby mrtvých z bitvy, je poloha Zabitý Důl, kde se podle dobové zprávy nacházelo rovněž velké množství lidských kostí. Další stopu po hrobech může naznačovat existence poloh Na malých hrobích a Na velkých hrobích.

11 Spojitelnost čtyř podkov s bitvou je nejasná (NZ čj. 1852/46, inv. č. 459-465). Naopak tři železné čtyřboké šipky, tři ostruhy s ozubeným kolečkem na bodlu a jeden železný předmět (NZ čj. 1853/46, inv. č. 455-458) by s bitvou skutečně souviset mohly. Kopí s ulomenou tulejkou, které daroval A. Šmejkal do Muzea Kouřimska v Kouřimi, by také mohlo být hmotným pozůstatkem bitvy (NZ čj. 6611/46). 


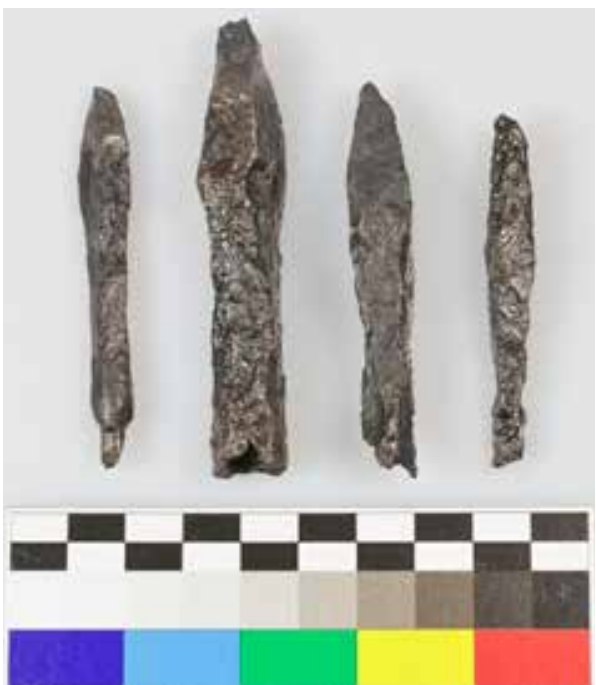

Obr. 3. Lipany. Výběr hrotů stř̌el z areálu bojiště, nalezených při archeologickém výzkumu v letech 2016-2017. Foto J. Pařez.

Abb. 3. Lipan. Auswahl an während der archäologischen Grabung in den Jahren 2016-2017 entdeckten Geschossspitzen vom Schlachtfeldareal. Foto J. Pařez.
Samotných terénních akcí, kterých zatím proběhlo za necelé tři roky výzkumu dvacet, se účastní malé badatelské skupiny, kdy připadá v průměru pět až šest hledačů na dobu šesti hodin jedné prospekce. Výzkumné týmy se skládají převážně z profesionálních archeologů a jejich dlouhodobých spolupracovníků, přičemž většina zúčastněných dlouhodobě používá detektory kovů při archeologických prospekcích. Samozřejmě vysoké procento nalezených předmětů $\mathrm{i} v$ tomto př́ípadě představuje odpad související se zemědělskou činností. Výrazné zamoření sledovaného území se často objevuje také v místech okolo regulovaných místních vodotečí.

Katastrální území obcí Lipany a Vitice patří do širší oblasti archeologicky bohatého Kolínska a úrodného středního Polabí, a proto se při detektorové prospekci areálu bojiště předpokládaly i archeologické nálezy spojené s pravěkými a raně středověkými aktivitami. $\mathrm{V}$ rámci doposud dokumentovaných nálezů v nich můžeme spolehlivě identifikovat artefakty z mladší doby bronzové, mladší doby římské i artefakty spojené s mladší fází raného středověku. Všechny tyto nálezy výrazně rozšiřují dosavadní povědomí o pravěkém a raně středověkém osídlení zkoumaného prostoru dohromady (Militká-Šámal 2017, 114-117; MilitkáBeneš-Šámal 2018, 663-678). Doklady osídlení v mladší fázi raného středověku reprezentují nálezy dvou zlomků záušnic. ${ }^{12}$ Povrchová prospekce na sledovaném území přinesla také nálezy několika olověných předmětů a slitků či zlomků. ${ }^{13}$ Např́íklad olověná kolečka menších průměrů mají analogie zejména $\mathrm{z}$ raně středověkých hradišt' (např. Mařík-Košta 2010), ale také ze sídlišst' (Macháček-Měchura 2013, 275-288; Bláha-Hejhal-Skala 2013, 289-306). Počet lokalit s nálezy těchto předmětů se radikálně zvýšil v závislosti na využívání detektorů kovů, bohužel funkce olověných koleček doposud nebyla uspokojivě vysvětlena (Militká-Beneš-Šámal 2018, 672-673).

Nálezů, které lze časově zařadit do pozdního středověku a které je možné vzhledem $\mathrm{k}$ jejich charakteru spojit s bitvou, je po necelých třech sezónách několik desítek. ${ }^{14} \mathrm{Na}$ prvém místě je nutné jmenovat militaria, která jsou zřetelným důkazem bojových aktivit. Ve sledovaném prostoru areálu bojiště je průběžně rozšiřován počet hrotů střel, které v současné době reprezentují necelé dvě desítky exemplářů. Některé z nich jsou zachovány pouze ve fragmentárním stavu, jiné jsou bez výrazného poškození (obr. 3 a 4). Hroty střel lze rozdělit do dvou skupin s tulejí a s trnem. Ve velikosti i hmotnosti těchto střel jsou značné rozdíly. Masivnější tvary jsou zastoupeny u hrotů střel s tulejí, výrazně subtilnější jsou hroty s trnem. Exempláře s trnem jsou rovněž střely používané do kuší, a nikoli luků, jak se někdy předpokládá. ${ }^{15}$ Svým charakterem zcela odpovídají nálezům z jiných zkoumaných středověkých míst konfliktu (Novobilský 2008;

12 Na pravděpodobnou existenci pohřebiště z mladši doby hradištní ukazuji i nálezy zlomků esovitých „cínových“ záušnic, které byly J. Fialou na konci 19. století předány do Národního muzea v Praze. Podle popisu $z$ archivu NM není jejich počet přesně znám.

13 Jedná se o nálezy olověných koleček různých průměrů (Militká-Beneš-Šámal 2018,672-673). Nejnovější a dosud nezpracované olověné nálezy z Lipan, které zřejmě souvisí s olověnými kolečky, jsou nálezy jedné plomby a olověného kolečka bez perforace. Tyto nálezy se objevují také v jiných známých nálezových souborech (Bláha-Hejhal-Skala 2013,303).

$14 \mathrm{U}$ vybraných předmětů byl proveden rentgenový průzkum a následně byla zajištěna jejich konzervace. V současné době jsou veškeré archeologické nálezy fotograficky zdokumentovány a zaneseny do databáze, která kromě fotografií obsahuje také slovní popis jednotlivých položek.

15 Za konzultaci z oboru militarií děkujeme Mgr. Michalu Pírkovi, PhD. (SNM Bratislava). 


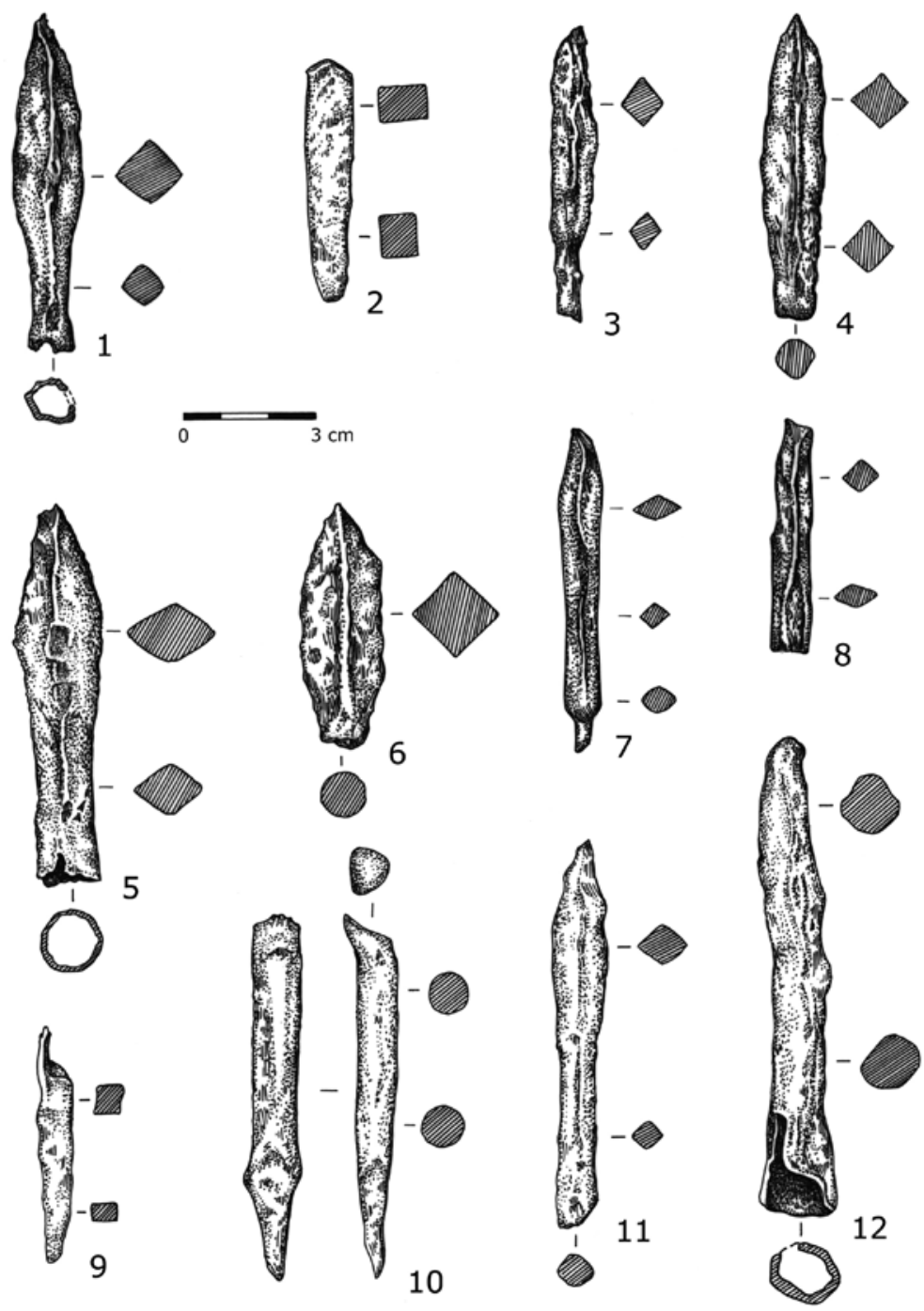

Obr. 4. Lipany. Tabulka I. Vybrané hroty střel z areálu bojiště zjištěné archeologickou prospekcí v roce 2016-2018. Kresba A. Waldhauserová.

Abb. 4. Lipan. Tafel I. Ausgewählte, durch archäologische Prospektion in den Jahren 2016-2018 entdeckte Geschossspitzen vom Schlachtfeldareal. Zeichnung A. Waldhauserová.

Koscelník-Kypta-Savková 2013, 574-598). Munici zastupují nálezy železných projektilů válcovitého tvaru (obr. 5), u jednoho exempláře je válcový projektil dutý (obr. 5, č. 2) - zřejmě byl původně vyplněn olovem. U některých projektilů je patrné poškození, které je dokladem deformace po nárazu. Další typ munice reprezentuje železná koule. Jinou kategorii nálezů představují pozůstatky výstroje bojovníků. K výbavě jezdce patří skupina zlomků ostruh (obr. 6), z nichž některé jsou zdobené (obr. 7). Podrobná typologická analýza jednotlivých skupin artefaktů je v současné době ve stadiu finálního zpracování a bude publikována na jiném místě.

Zatímco předchozí popsané nálezy lze spojovat prakticky s jistotou s bitvou roku 1434 , u dalších nálezů spadajících do pozdně středověkého období je přímý vztah s konfliktem pouze 


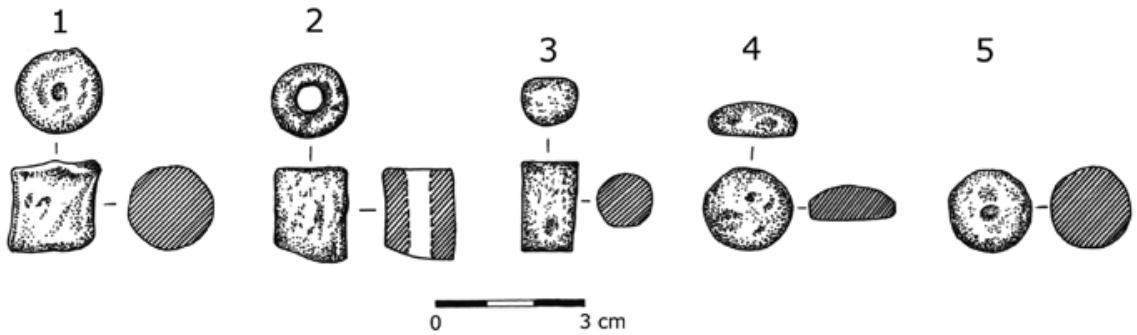

Obr. 5. Lipany. Tabulka II. Výběr železných válcových projektilů z prostoru bojiště. Kresba $\mathrm{A}$. Waldhauserová. Abb. 5. Lipan. Tafel II. Auswahl an zylinderförmigen Eisenprojektilen aus dem Raum des Schlachtfeldes. Zeichnung A. Waldhauserová.

hypoteticky možný. Určitě zajímavým nálezem je měděný husitský haléř se lvem, tzv. flútek, který lze datovat do průběhu 20., ale možná ještě i do 30 . let 15 . století. ${ }^{16}$ Rovněž v tomto př́ípadě je však vztah nálezu k okamžiku konfliktu nejasný, mince se mohla na pole dostat s vyvážením odpadu s hnojem z některé z okolních vsí. Mezi zajímavé artefakty patř́i také nález štítku pozdně stř̌edověkého prstenu - podle analogií by se však mohlo jednat i o artefakt mladší, datovatelný do průběhu 15. století (Litauszki 2012, tab. 7).

Početně výraznou skupinu nálezů tvoří artefakty novověkého, případně pozdně středověkého stáŕí, které však ve většině případů s bitvou spíše nesouvisejí. Poměrně vysoké procento $\mathrm{z}$ celkového nálezového souboru tvoří podkovy. ${ }^{17}$ Koňské podkovy jsou v souboru zastoupeny zatím 19 zlomky. Ty budou podrobeny dalšímu odbornému zkoumání, nicméně již nyní známe analogie (Kaźmierczyk 1978; Krajíc 2006; Kuba 2016), které ukazují na středověké stáří několika z nich. Pak by teoreticky a s velkou opatrností mohly být snad spojovány s bitvou. Ve sledovaném souboru se objevilo šest exemplářů okování bot, tzv. podkůvek, které však budou podle dosavadních analogií raně novověkého stáří (Cymbalak 2006; 2012). Také další železné předměty, například hřeby, zlomky kličů či nožů, souvisejí především se životem v okolních vsích. Jedná se často o nálezy chronologicky velmi málo citlivé.

Dosavadní výsledky archeologické prospekce pomocí detektoru kovu zatím v několika ohledech vykazují shodu s výpovědí písemných pramenů. Jak je patrno z mapového podkladu (obr. 8), do kterého byly zaneseny veškeré získané nálezy, jsou zde zřetelná místa s výraznější koncentrací nálezů takového charakteru, že je lze spojovat s vrcholně středověkým vojenstvím. Jedná se zejména o hroty střel, které byly nalezeny v místech, kde mělo hypoteticky dojít ke střetu obou vojsk. Další kumulace nálezů je ve spodní části západního svahu Lipské hory, kam písemné prameny zasazují vojenský tábor radikálů. Zajímavé jsou i ojedinělé nálezy železných projektilů, které byly detekovány v prostoru, kam písemné prameny kladou směry ústupových cest z bojiště. Samozřejmě že je při vyhodnocení nálezové situace brán zřetel na dlouhodobé a intenzivní zemědělské využívání areálu bojiště, které může posouvat nálezy v ornici z místa původního dopadu při samotném střetu. Zdá se, že i přes depoziční procesy mohou být u nálezů souvisejících s bitvou poměrně dobře zachovány prostorové vztahy.

\section{Závěr}

Po necelých třech sezónách systematické archeologické prospekce je zřejmé, že zájmové území není definitivně nevědecky zničeno nelegálními destruktivními zásahy a poskytuje některé zásadní informace umožňující formulovat nové hypotézy a poskytující badatelům orientační body $\mathrm{k}$ hledání poloh vojenských ležení obou znepřátelených stran v hodinách těsně před

16 Za určení děkujeme PhDr. Jiřímu Militkému, Ph.D. (NM Praha).

$17 \mathrm{Z}$ nich je mimořádné množství tzv. volských podkov. Jejich výrazné zastoupení v celém nálezovém souboru evokuje otázku, zda je takové vysoké množství běžným jevem na českých polích, kde se po staletí používal skot jako tažná síla při orbě, či je tento jev u Lipan něčím výjimečným. Zatím zůstává tato otázka nezodpovězená. 

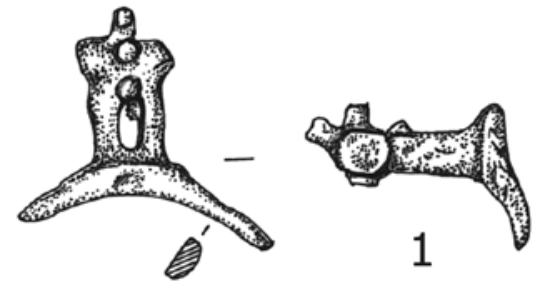

2

0
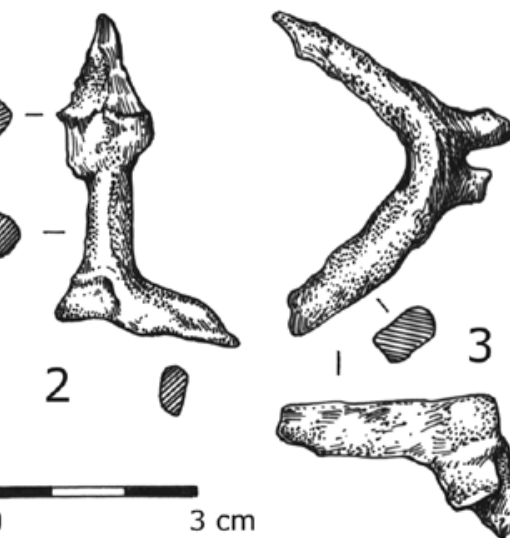

।

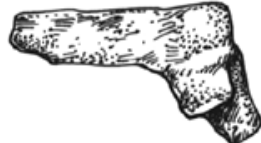

Obr. 6. Lipany. Tabulka III. Zlomky ostruh. Kresba A. Waldhauserová.

Abb. 6. Lipan. Tafel III. Sporenfragmente. Zeichnung A. Waldhauserová.

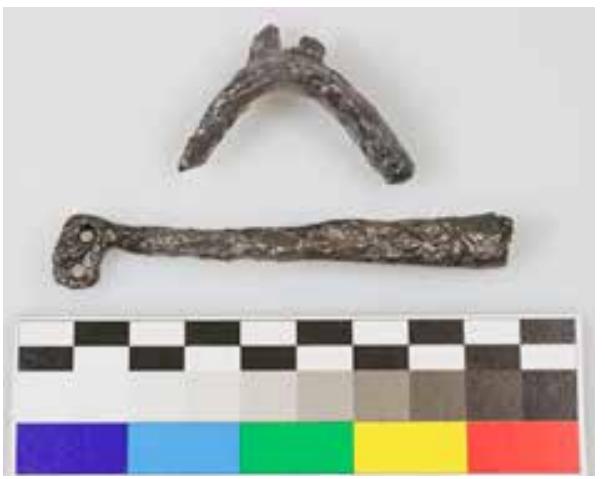

Obr. 7. Lipany. Výběr fragmentů ostruh. Foto J. Pařez. Abb. 7. Lipan. Auswahl an Sporenfragmenten. Foto J. Pařez.

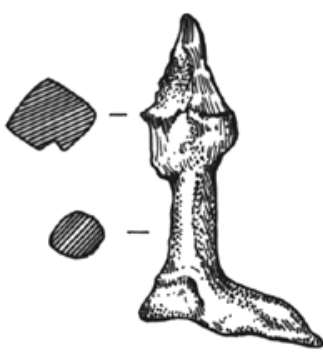

propuknutím bitvy. V této souvislosti je třeba znovu zdůraznit, že odborně vyzvednuté archeologické nálezy s lokalizací pomocí souřadnic systému GPS jsou vlastně prvními nálezy z místa osudové bitvy českých dějin, které mají zachovány prostorové vztahy, a mohou tak pomoci při řešení otázek spjatých s průběhem vojenské operace. Dosavadní terénní prospekce lipanského bojiště nesporně otevírá novou kapitolu možností dokumentace a aktivní ochrany bojišt' na českém území. $\mathrm{V}$ neposlední řadě archeologický výzkum nastolil otázky, jak aktivně eliminovat rizika poničení archeologických lokalit $\mathrm{v}$ zemědělské krajině, kde nejsou na první pohled jasné archeologické relikty, jako je tomu např́íklad v lesním prostředí.

Výzkum bojiště u Lipan zatím z hlediska objemu nálezů s pravděpodobným vztahem k bitvě z 30. května 1434 nelze hodnotit jednoznačně. Co do počtu artefaktů na jedné straně nedosahuje výsledků některých velkoryse zkoumaných středověkých bojišt' $\mathrm{v}$ jiných evropských zemích, jako např́iklad Grunwald (Nowakowski 2015, 79-87), Bosworth (Foard-Curry 2013) nebo Moháč (SzabóBertók-Gáti-Szajcsán 2016). Na druhé straně lipanské výsledky jiné průzkumy předčí. Např́iklad při výzkumu Bannockburnu bylo po prospekci za využití detektorů kovů možné spojit se samotnou bitvou pouze čtyři nalezené artefakty (Biederman a kol. 2018, 42; Šámal 2018, 16-20). Významnou roli v tom hraje skutečnost, že výzkum u Lipan probíhá v komorních podmínkách, kdy se odborné vedení opírá o početně malou skupinu dobrovolníků a občasných spolupracovníků.

Důvody jisté „nálezové nouze“ ale nutno hledat i ve vojenské taktice a zvyklostech husitských válek. Tehdy se sice plánovitě v širším měřítku uplatňovaly střelné a palné zbraně, ale jejich užití $v$ průběhu dynamického střetu $\mathrm{v}$ otevřeném terénu nedosahovalo intenzity charakteristické pro dlouhodobější obléhání hradů a pevností. Z písemných pramenů je zřejmé, že střelba hrála v bitvě u Lipan spíš symbolickou úlohu jen v jejím úvodu a boje pak probíhaly kontaktním způsobem ,,muže proti muži“, kdy rozhodovaly bodné, sečné a úderné zbraně. Výzkumy v okolí fortifikací exponovaných v době husitských a poděbradských válek ukazují, že tohoto typického spotřebního materiálu vojenské povahy (hroty střel do kuší a olověných projektilů) zůstávalo na místě poměrně značné množství a tento materiál má v návaznosti na prostorová data významnou výpovědní hodnotu. Něco takového ale u Lipan z logiky věci chybí. 


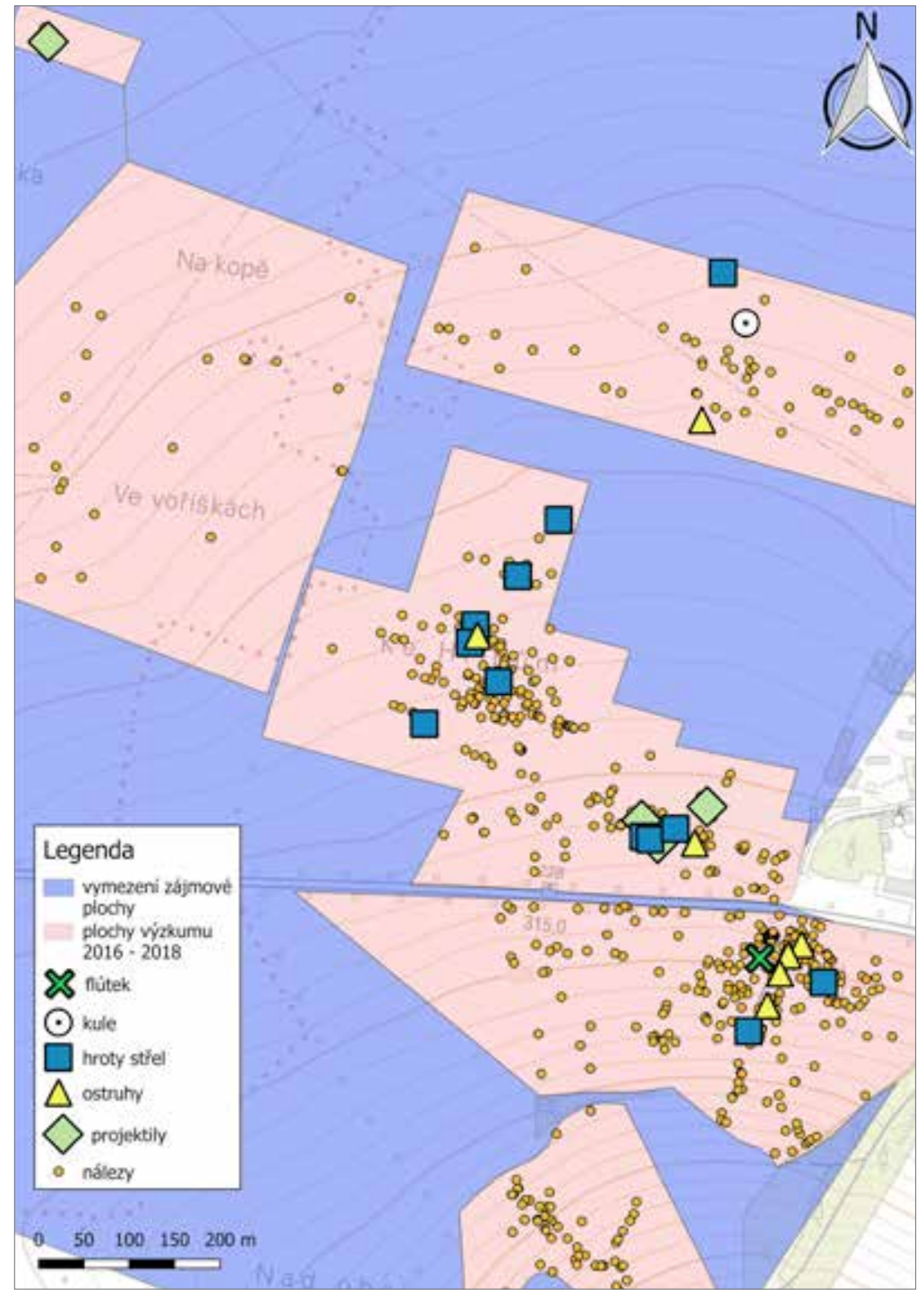

Obr. 8. Lipany. Mapa zájmového území s vyznačenými plochami archeologické terénní prospekce v letech 2016-2018. Zdroj podkladových dat ČÚZK, WMS-ORTOFOTO (2017-12-17).

Abb. 8. Lipan. Karte des Interessensgebietes mit gekennzeichneten Flächen der archäologischen Geländeprospektion von 2016-2018. Quelle Basisdaten des Tschechischen Amtes für Landesvermessung und Kataster, WMS-ORTOFOTO (2017-12-17).

Dalším důležitým faktorem je i povaha zkoumaného terénu - v půdě po staletí obdělávané $\mathrm{v}$ rámci pravidelného hospodářského cyklu nelze očekávat nálezy střel v intaktních situacích, stejně jako je nutné počítat s tím, že korodující železo je opakovaně fragmentováno zemědělskou technikou. Absence výraznějších kusů výzbroje a výstroje je pak výsledkem toho, že vítězná strana obvykle pobrala většinu věcí pohozených na bojišti jako legitimní kořist. O drobnější zbytky se pak stejně spolehlivě postarali ti, kteří pohřbívali mrtvé. Proto se stávající nálezový 
fond kromě hrotů střel a projektilů opírá i o další typické spotřební artefakty, či lépe řečeno jejich drobnější fragmenty, zahrnující především jezdeckou výstroj (ostruhy, třmeny, podkovy).

Stále nedořešenou badatelskou výzvu v případě bitvy v prostoru mezi dnešními obcemi Lipany a Hřiby pak představuje i fakt, že obě vojska na místě tři dny tábořila a nutně zde zanechala stopy potenciálně zachytitelné detektorem kovů. Určitou hypotézu opřenou o nálezovou situaci a analýzu terénu nabízí možná poloha vozového ležení radikálů, v případě koaličního tábora však opěrné body v podobě větší koncentrace nálezů zatím zcela chybí.

Často kladenou a doposud nezodpovězenou otázkou zůstává, kde jsou pohřbena těla padlých vojáků, avšak tato problematika aktuálně přesahuje rámec tohoto projektu.

Př́spěvek je jedním z výstupů projektu realizovaného v rámci výzkumného cíle Archeologie, financovaného z institucionální podpory Ministerstva kultury dlouhodobého rozvoje (DKRVO 99H3010010) výzkumné organizace NPÚ.

\section{Prameny a literatura}

NZ čj. 1852/46: Archiv nálezových zpráv AÚ AV ČR, v. v. i., Praha, čj. 1852/46.

NZ čj. 1853/46: Archiv nálezových zpráv AÚ AV ČR, v. v. i., Praha, čj. 1853/46.

NZ čj. 6611/46: Archiv nálezových zpráv AÚ AV ČR, v. v. i., Praha, čj. 6611/46.

BEDNAŘÍK, K., 1959: Kde byl pohřben Prokop Veliký, Vesnické noviny Českobrodského okresu 10, 29. 5. 1959.

BENEŠ, J.-KUBŮ, F.-TÖRÖK, J., 2005: Soubor militarií z počátku třicetileté války z Volarských šancí, AR XLVII, 461-480.

BLÁHA, R.-HEJHAL, P.-SKALA, J., 2013: Raně středověké olověné artefakty z katastru Roudnice (okr. Hradec Králové). In: Argenti fossores et alii (Boroń, P., red), 289-306. Wrocław.

BLAŽKOVÁ, K. a kol., edd., 2001: Bitva u Rakovníka 1620. Rakovník.

BIEDERMAN, J. a kol., 2017: Biederman, J.-Čornej, P.-Militká, L.-Šámal, Z., Archeologický výzkum bojiště u Lipan 1434 a jeho př́nos k poznání významné dějinné události. První etapa výzkumu, ZPP 77 - Př́loha, 1-10.

BIEDERMAN, J. a kol., 2018: Biederman, J.-Čornej, P.-Militká, L.-Šámal, Z., Středověké bojiště u Lipan ve světle poznatků historických disciplín a probíhajícího archeologického výzkumu, Historie a vojenství 3, 32-51.

BROCK, T.-HOMANN, A., 2011: Schlachtfeld-Archäologie: Auf den Spuren des Krieges. Sonderband 2011 der Zeitschrift Archäologie in Deutschland. Stuttgart.

CYMBALAK, T., 2006: Wybrane znaleziska podkówek do butów z terenu Czech na tle analogii środkowo-europejskich, Archaeologica Pragensia 18, 263-282.

- 2010: Nálezy podkůvek na obuv na území České republiky ve středoevropském kontextu - nové poznatky. In: Acta musealia Muzea jihovýchodní Moravy ve Zlíně 2012. Sborník materiálů z VI. mezinárodní konference - Obuv v historii, 183-201. Zlín.

ČORNEJ, P., 1992: Lipanská křižovatka. Př́ičiny, průběh a historický význam jedné bitvy. Praha.

HEBER, A., 2012: České hrady, zámky a tvrze. Čtvrtý díl. Střední Čechy. Praha.

HOLAS, M., 2017: Detektorový průzkum části náchodského bojiště v roce 1866, Historie a vojenství 1, $18-23$.

HOMANN, A., 2013: Battlefield Archaeology of Central Europe - With a Focus on Early Modern Battlefields. In: Historical Archaeology in Central Europe (Mehler, N., ed.), 203-230. Rockville, MD.

HRNČIŘÍK, P., 2012: Příspěvek k nálezům munice v prostoru bojiště Rozvadov 1621 - souhrn za období 2010-2012, Sborník muzea Českého lesa v Tachově 32/11, 17-21.

- 2013: Příspěvek k nálezům munice v prostoru bojiště Rozvadov 1621 - souhrn za období 2010-2012, Sborník muzea Českého lesa v Tachově 33/13, 17-32.

FOARD, G.-CURRY, A., 2013: Bosworth 1485. A Battlefield Rediscovered. Oxford.

JÁNSKÁ, E., 1963: Archeologický výzkum hradu Sión, AR XV, 220-247.

KAŹMIERCZYK, J., 1978: Podkowy na Ślasku w X-XIV wieku. Wrocław - Warszawa - Kraków - Gdańsk. KOSCELNÍK, P., 2013: Archeologie konfliktních areálů v Čechách v 15. století. Disertační práce, ulož. na KAR FF ZU Plzeň. 
KOSCELNÍK, P.-KYPTA, J.-SAVKOVÁ, E., 2013: Obléhání hradu Sion roku 1437. Povrchový průzkum palebných postavení obléhatelů, AR XLV, 574-598.

KRAJÍC, R., 2006: Sezimovo Ústí - archeologie středověkého poddanského města 3. 2. díl. Praha.

KRÁSNÝ, F., 2014: Problematika detektorů kovů v archeologii. Rkp. diplomové práce, ulož. v Ústavu pro pravěk a ranou dobu dějinnou FF UK, Praha.

KYPTA, J.-PODLISKA, J., 2014: Tábor obléhatelů na předpolí Nového hradu u Kunratic (1420/1421). Povrchový průzkum a srovnání s analogickými lokalitami, AR XLVI, 609-632.

KUBA, A., 2016: Podkovy z hradu Rokštejna. Morfologická analýza podkov 10.-15. století ve vztahu k druhu koně. Rkp. bakalářské práce, ulož. v ÚAM FF MU, Brno.

KUFFNER, H.-MIŠKOVSKÝ, J., 1899: Bitva u Lipan 30. května 1434. Český Brod.

LEHKÝ, I.-SÝKORA, M., edd., 2017: Kalich a Panna. Hrady Jana Žižky. Most.

LITAUSZKI, Z., 2012: Árpád- és késő középkori pecsétgyűrűk A dél-alföldi régióban. Kutatások bács-kiskun, békés és csongrád megyében. Szegedi tudományegyetem Bölcsészettudományi kar. Szeged.

MACHÁČEK, J.-MĚCHURA, R., 2013: Raně středověké olovo z jižní Moravy a hutnické centrum na Slezsko-krakovské vysočině. In: Argenti fossores et alii (Boroń, P., red.), 275-288. Wrocław.

MAŘÍK, J.-KOŠTA, J., 2010: Archeologická mapa raně středověké Libice, výzkumy Rudolfa Turka na akropoli hradiště (DVD). Praha.

MATOUŠEK, V., 2003: Předběžná zpráva o 2. a 3. sezoně archeologického výzkumu bojiště u Rozvadova z roku 1621, Sborník muzea Českého lesa v Tachově 33/11, 3-14.

- 2006: Třebel. Obraz krajiny s bitvou. Praha.

MATOUŠEK, V. a kol., 2011: Zpráva o první sezoně systematického archeologického výzkumu bojiště z roku 1621 u Rozvadova, Sborník muzea Českého lesa v Tachově 32/1, 3-14.

MATOUŠEK, V.-HRNČIŘÍK, P.-ŠÁMAL, Z., 2018: Rozvadov 1621. Výzkum bojiště třicetileté války. České Budějovice.

MEDUNA, P., 1994: Povrchový průzkum komplexu obléhacích prací u Konopiště z let 1467-1468, CB 4, $243-250$.

MILITKÁ, L.-BENEŠ, Z.-ŠŚMAL, Z., 2018: Nové pravěké a raně středověké nálezy z areálu bojiště u Lipan, okr. Kolín, ASČ 22, 663-678.

MILITKÁ, L.-ŠÁMAL, Z., 2017: Nález antoninianu císaře Trainana Decia u Lipan (okr. Kolín), Numismatický sborník 30, 114-117.

NOVOBILSKÝ, M., 2008: Obléhání hradu Lopaty. Rekonstrukce obléhání hradu z roku 1432-1433. Plzeň.

NOWAKOWSKI, P. A., 2015: Sprawozdanie z badań archeologicznych prowadzonych na terenie Pól Grunwaldu w dniach 4.-24. 09. 2014 r., Nowe Studia Grunwaldzkie I, 79-87.

OLIVA, O., 1954: Kde byl pohřben Prokop Veliký. Separát z IV. svazku Historie a vojenství. Praha.

PÍČ, J. L., 1891: Archeologický výzkum ve středních Čechách, PA XV, 199-411.

POLlARD, T., 2009: The Rust of Time: Metal Detecting and Battlefield Archaeology. In: Metal Detecting and Archaeology (Thomas, S.-Stone, P., edd.), 181-202. Suffolk.

PÖPPELMANN, H.-DEPPMEYER, K.-STEINMETZ, W. D., edd., 2013: Roms vergessener Feldzug. Die Schlacht am Harzhorn. Veröffentlichungen des Braunschweigischen Landesmuseums. Darmstadt.

PRÁŠEK, J. V., 1892: Zápis z komise. Ostatní sdělení, PA XV, 632.

PRKNO, J.-VÁVRA, M.-ZAPÁŘKA, L., 1987: Lipany, okr. Kolín. In: Výzkumy v Čechách 1984-85, 109. Praha.

- 1987: Vitice, okr. Kolín. In: Výzkumy v Čechách 1984-85, 225. Praha.

SCOTT, D. D., 2010: Uncovering History: The Legacy of Archeological Investigations at the Little Bighorn Battlefield National Monument. Montana.

SCHLÜTER, W., 1992: Archäologische Zeugnisse zur Varusschlacht? Die untersuchungen in der Kalkrieser-Niewedder Senke bei Osnabrück, Germania 70, 307-402.

SCHÜRGER, A., 2009: Die Schlacht von Lützen 1632: Archäologische Untersuchungen auf dem linken kaiserlichen Flügel. In: Schlachtfeldarchäologie - Battlefield Archaeology, Tagungen des Landesmuseums für Vorgeschichte Halle, 135-149. Halle.

SKLENÁŘ, K., 2011: Pravěké a raně středověké nálezy v Čechách do roku 1870. Pramenná základna romantického období české archeologie. Praha.

SKOPEC, J., ed., 1924: Paměti Františka J. Vaváka, souseda a rychtáře milčického, z let 1770-1816. III/4. Praha.

STRNAD, J., ed., 1891: Listář královského města Plzně a druhdy poddaných osad. Část I. Od r. 1300-1450. Plzeň.

SUTHERLAND, T.-HOLST, M., 2005: Battlefield Archaeology - a Guide to the Archaeology of Conflict. London. 
SZABÓ, M.-BERTÓK, G.-GÁTI, C.-SZAJCSÁN, E., 2016: Mohács Battlefield Survey. The Lesson From the First National Archeological Metal Detecting Rally, Hungarian Archealogy (e-Journal). Dostupné z: http://files.archaeolingua.hu/2016NY/Szabo_et_al_E16NY.pdf, cit. 23. 3. 2019.

ŠÁMAL, Z., 2001: Archeologové na bojišti. Několik poznámek k detektorovému průzkumu rakovnického bojiště z roku 1620. In: Bitva u Rakovníka 1620 (Blažková, K. a kol., edd.), 50-59. Rakovník.

- 2018: Bojiště u Rakovníka 1620. Př́íspěvek k problematice detektorové prospekce raně středověkých bojišt'. Rkp. bakalářské práce, ulož. na FF UK, Praha.

ŠTUKA, Č.-NOVÝ, P., 2015: Čertova brázda ve vztahu ke starým cestám. In: Výzkum historických cest v interdisciplinárním kontextu 2 (Martínek, J., ed.), 39. Brno.

URBÁNEK, R., 1934: Lipany a konec polních vojsk. Praha.

VÍCH, D., 2017: Projectile head finds from Zítkov Castle near Choceň, Acta Militaria Mediaevalia XIII, 83-109.

\section{Zusammenfassung}

\section{Archäologische Prospektion des hochmittelalterlichen Schlachtfeldareals bei Lipan (Bezirk Kolín)}

Hauptziel des seit 2016 bereits in der dritten Saison laufenden Projektes ist das Bestreben, den Raum der in der Geschichte Böhmens bedeutenden Schlacht, in der am 30. Mai 1434 radikale Hussiten mit der Allianz zwischen Katholiken und gemäßigten Utraquisten zusammenstießen, so genau wie möglich zu bestimmen. Eine weitere wichtige Aufgabe ist auch die Gewährleistung einer aktiven archäologischen Denkmalpflege für die potenziell bedrohte Fundstelle, die Nutzer von Metalldetektoren langfristig zu illegalen Besuchen anlockt. Die Untersuchung verbirgt auch nicht Ambition, mobile archäologische Funde im voraus zu dokumentieren, denen eine Hebung aus dem Erdreich ohne fachkundige Aufsicht droht.

Vom Programm her basiert das Projekt auf dem Prinzip der Interdisziplinarität. Dessen Grundpfeiler ist die Geländeidentifikation und die Dokumentation des Schlachtfeldareals anhand von Standardmethoden sowie mittels neuer Dokumentationsmethoden. Im Falle einer archäologischen Fundstelle dieses Typs zählt eine vollkommene Vertrautheit mit Aussehen und Interpretationen der schriftlichen und auch ikonographischen Quellen, die sowohl das einzigartige historische Ereignis, als auch dessen breiteren historischen Kontext reflektieren, zur vorrangigen Forscherpflicht. Die Ergebnisse der bisherigen drei Saisons der Geländeprospektion des Schlachtfeldes von Lipan lassen das bisher nicht völlig zutage geförderte Informationspotenzial der archäologischen Quellen erkennen, deren gebührende Bearbeitung die Quellengrundlage zur Geschichte des Territoriums der Tschechischen Republik beträchtlich bereichert.

Der vorliegende Beitrag ist einer der Outputs des im Rahmen der Forschungsziele der Archäologie realisierten Projektes und wird vom Ministerium für Kultur durch die institutionale Förderung der langfristigen Entwicklung (DKRVO 99H3010010) der Forschungsorganisation Nationales Denkmalamt finanziert.

Mgr. Lenka Militká, Národní památkový ústav, Valdštejnské náměstí 3, 11800 Praha 1, Česká republika, militka.lenka@npu.cz

Mgr. Zdeněk Šámal, Česká televize, Kavčí hory, 14000 Praha 4, Česká republika, zdenek.samal@ceskatelevize.cz 
